Manuscript received 09.07.2020

Accepted: 16.07.2020

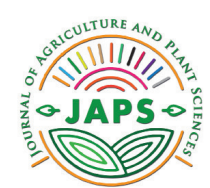

In print: ISSN 2545-4447

On line: ISSN 2545-4455 doi: https://doi.org/10.46763/JAPS2010049p Original scientific paper

\title{
HEALTHCARE OF THE IMPORTED POTATO SAMPLES IN THE REPUBLIC OF NORTH MACEDONIA
}

\author{
Maja Petruseva ${ }^{1 *}$, Sasa Mitrev², Emilija Arsov² \\ ${ }^{1}$ Goce Delcev University - Stip, Faculty of Agriculture, \\ Republic of North Macedonia, MSc student \\ ${ }^{2}$ Goce Delcev University - Stip, Faculty of Agriculture, \\ Department for Plant and Environmental Protection, Republic of North Macedonia \\ ${ }^{*}$ Corresponding author: mristevska62@yahoo.com
}

\begin{abstract}
This study relates to performing healthcare of seed and mercantile potatoes on imports, as well as sampling at cross border entry points in the Republic of North Macedonia, for the period 2014-2017. Plant pathogens control is in accordance with the monitoring programme for seed and mercantile potatoes in our country, and refer to the presence or absence of the following most important harmful organisms such as: bacterial diseases - wilt and brown potato rot - Ralstonia solanacearum and potato ring rot - Clavibacter michiganensis subsp. sepedonicum; fungal pathogens - potato cancer - Synchitrium endobioticum perc.; and cyst nematodes - Globodera pallida (Stone) Behrens and Globodera rostochiensis (Wollenweber) Behrens on potatoes (Islam. and Chowdhury, 1998). All samples, were laboratory tested at State Phytosanitary Laboratory, and a health status with absence of harmful organism was confirmed.

Individually, both, by years, and total for all years, from the period of investigation 2014 until 2017, a survey at "Tabanovce", cross-border point has the highest number of both performed, visual health examinations and laboratory analyzed samples. The largest import of mercantile potatoes was in 2014 at $3.044 \mathrm{t}$, and at least in 2017110 t. The largest import of seed material was imported in 2017 at 7.386 t, while the least imported in 2016 was 842 t. For the period 2014 to 2017, annual import averaged about 2.680 t of seed potatoes and 1.368 $\mathrm{t}$ of mercantile potatoes.

This research explains, for the first time, the importance of mercantile and seed potatoes import in the Republic of North Macedonia from the abroad in the three cross border places, and the quantity and quality of imported material. This study confirmed that the presence of the following harmful organisms (Ralstonia solacearum, Clavibacvter michiganensis ssp. sepedonicus; Synchitrium endobioticum; Globodera pallida and Globodera rostochiensis, has not been established (no introduction, occurrence and further spread).
\end{abstract}

Key words: potatoes, harmful organisms, imports, cross-border

\section{INTRODUCTION}

Potato (Solanum tuberosum L.) is a very important crop as a food source in the diet of humans, livestock, in the food industry for the production of alcohol and starch, as it contains a large amount of starch, a protein high in vitamins such as: A, B1, B2, B6, C, mineral substances and trace elements. By its economic importance it is measured with wheat, maize, but in areas where there are no optimal conditions for its cultivation, it comes first. In Europe, it is important because it has contributed to the eradication of hunger, and today it occupies a major place in human nutrition (FAO STAT, 2012).
The focus of our research includes sampling properly at the points of entry into the Republic of North Macedonia, the manner, procedures and procedures of the sampling itself, in order to obtain relevant data to prove the presence or absence of certain harmful organisms on the territory of the Republic of North Macedonia (Official Gazette of the Republic of Northern Macedonia" No. 29/05, 81/08, 20/09, 57/10, $17 / 11,148 / 11,69 / 13,43 / 14$ and 158/14).

The main aim was the analysis of the annual reports on visual health examinations and analyzed laboratory samples, as well as 
the cross border in the investigated period. The results of the annual data were processed by arithmetic mean, percentage difference between visual examinations and laboratory analyzes, sum of samples taken, error of mean for confirmation of arithmetic mean, median as a number indicating the mean value of samples taken, standard deviation which determines the variability in the data set itself.
In this research, health conditions and laboratory analyzed samples, where the smallest deviation confirms the data are close to the mean, and the larger that the obtained samples for laboratory analysis are in a wider range of values which determines the dispensability of the performed visual health examinations and samples.

\section{MATERIAL AND METHODS}

Our research has processed all available data resulting from the implementation of phytosanitary monitoring in the field of health of plants, which is a regular annual activity that includes systematic collection, processing and data on the presence of certain harmful organisms in the Republic of North Macedonia.

Phytosanitary monitoring includes conducting a health examination, sampling for laboratory analysis, monitoring the state of health of the plants and systematic control of the infected, endangered and non-infected areas, was first implemented in 2013, and its implementation has continued to establish the presence of daily absence of quarantine and certain economically harmful organisms.

The importance and uniqueness of this research is derived from obtaining a relevant and complete picture of the import of seed and mercantile potatoes throughout our country, with particular emphasis on the Tabanovce cross-border point, considering other crossborders.

Completeness refers to the processing of data over a four years period from 2014 to 2017, both annual analyzes for each year individually and for total data for all years. The implementation of the prescribed procedures and procedures through this research provides a complete picture of the health phytosanitary control performed by the state phytosanitary inspectors, which are in accordance with EU standards in order to obtain relevant data on the presence or absence of harmful phytosanitary organisms in seed and mercantile potatoes (Official Gazette of the Republic of Northern Macedonia", no.151/14; Official Gazette of the Republic of Northern Macedonia" No. 65/10; Official Gazette of the Republic of Northern Macedonia" No. 88/00).
Our research begins at the cross-boarding as they are the first barrier to prevent the introduction of harmful organisms, and thus prevent the emergence and further spread of harmful organisms on the territory of our country, which are imported by importing seed material of potatoes. The Republic of North Macedonia, unfortunately due to a series of disadvantages, all the seed potato material used for production comes from abroad, as there is no selection of seed planting material. Small exceptions are the small individual producers that produce for their own purposes and are of negligible character. Particular emphasis is placed on phytosanitary control at the Tabanovce border crossing point, as imports of almost all potato seed material come from the Netherlands, followed by Germany. The place of entry is Tabanovce cross-border point by road, truck traffic.

Visual health examinations and samples taken for further analysis in seed and mercantile potatoes to prove presence or absence refer to the following harmful organisms:

- Bacterial wilt and brown potato rot Ralstonia solanacearum

- Potato cancer - Synchitrium endobioticum perc.

- Potato ring rot - Clavibacter michiganensis subsp. sepedonicum

- nematodes Globodera pallida (Stone) Behrens and Globodera rostochiensis (Wollenweber) Behrens in potatoes (Official Gazette of the Republic of North Macedonia" no. 62/17; Official Journal of the Republic of North Macedonia" no. 34/14; 'Official Journal of the European Communities Republic of North Macedonia" no. 62/1).

The samples are submitted to the State 
Phytosanitary Laboratory, Department of Diagnostics. On a recent supervisory visit by the Accreditation Institute of the Republic of North Macedonia (IARNM), State Phytosanitary Laboratory was assessed as a laboratory in an ever-evolving process of improving the quality management system and implementing new advanced methods in all areas of diagnostics, bringing the number of accredited methods are constantly increasing. For our research, the subject is potato tubers and soil from border crossings. Laboratory analyzes of the examined organisms in mercantile and seed potatoes are carried out by the following methods:

*EPPO standard CD 2006/63 / EC, 2006 Immunofluorescence test (IC test) for the detection and identification of Ralstonia solanacearum in potato tubers. Plant material: (200 tubers) * EPPO standard CD 2006/56 / EC, 2006 Immunofluorescence test (IC test) to prove and identify the bacterium Clavibacter michiganensis ssp. sepedonicus in Potato Tubers Plant Material: (200 Tubers) * EPPO PM 7/28 (1), 2003 Evidence and identification of Synchytrium endobioticum by macroscopic visualization and microscopy in potato tubers. Plant material: (200 tubers)

*Methods for soil nematode extraction, 2b Cotton Filter Method (Oostenbrink, 1960 \& Townshend, 1963) Procedure for proving the presence of Globodera pallida and Globodera rostochiensis in soil. Material: soil

\section{RESULTS AND DISCUSSION}

After the laboratory analysis, State phytosanitary laboratory submits a Report confirming the presence or absence of the harmful organism.
Table 1 and Figure 1.2014 show that almost all of the seed material in terms of the number of visual health examinations and analyzed samples was performed at Tabanovce (24).

Table 1. Number of healthcare performed (visual and laboratory analysis) of mercantile and seed material imported in 2014 at three cross-borders.

\begin{tabular}{|c|c|c|c|c|c|}
\hline $\begin{array}{l}\text { Cross- } \\
\text { boarder }\end{array}$ & Material & $\begin{array}{r}\text { Number } \\
\text { of visual } \\
\text { healthcare }\end{array}$ & $\begin{array}{r}\text { Total number } \\
\text { of samples for } \\
\text { analyses }\end{array}$ & $\begin{array}{r}\text { Difference / } \\
\text { Number / } \\
\text { samples }\end{array}$ & $\begin{array}{r}\% \text { analyses/ } \\
\text { Check number }\end{array}$ \\
\hline \multirow{2}{*}{ Tabanovce } & Mercantile & 24 & 12 & 12 & $-50 \%$ \\
\hline & Seeds & 24 & 23 & 1 & $-4 \%$ \\
\hline \multirow{2}{*}{ Kafasan } & Mercantile & 9 & 2 & 7 & $-78 \%$ \\
\hline & Seeds & 0 & 0 & 0 & $0 \%$ \\
\hline \multirow{2}{*}{ Blace } & Mercantile & 11 & 11 & 0 & $0 \%$ \\
\hline & Seeds & 1 & 1 & 0 & $0 \%$ \\
\hline \multicolumn{2}{|c|}{ Total number } & 69 & 49 & 20 & $-29 \%$ \\
\hline \multicolumn{2}{|c|}{ Average } & 11.5 & 8.2 & 3.3 & $-29 \%$ \\
\hline \multicolumn{2}{|c|}{ Medium value error } & 4.3 & 3.6 & & \\
\hline \multicolumn{2}{|l|}{ Mediana } & 10.0 & 6.5 & & \\
\hline \multicolumn{2}{|l|}{ Modus } & 24.0 & 0.0 & & \\
\hline \multicolumn{2}{|c|}{ Standard deviation } & 10.6 & 8.9 & & \\
\hline \multicolumn{2}{|c|}{ Minimum } & 0.0 & 0.0 & & \\
\hline \multicolumn{2}{|l|}{ Maximum } & 24.0 & 23.0 & & \\
\hline
\end{tabular}

The percentage of visual health cares, compared to total samples taken for laboratory analysis differs in terms of mercantile and seed material. Thus, at the Tabanovce BCP a total of 24 visual health examination of mercantile material was performed, while laboratory analyzes were performed on 12 samples. In the field of seed material both in terms of the number of laboratories analyzes performed 23 and in the field of visual health examinations 24 is much higher.

Whereas the difference between total samples taken for laboratory analysis in terms of the number of performed health examinations is 20 samples or $29 \%$ more than the number of visual health examinations performed. The 
average rehearsals for all three border crossings for this year amounted to 11.5 number of visual health examinations performed, 8.2 total samples taken for laboratory analysis. 5. The deviation is not very high and without much variability with respect to the visual (10.6) and analyzed samples (8.9) shown in Table 1.

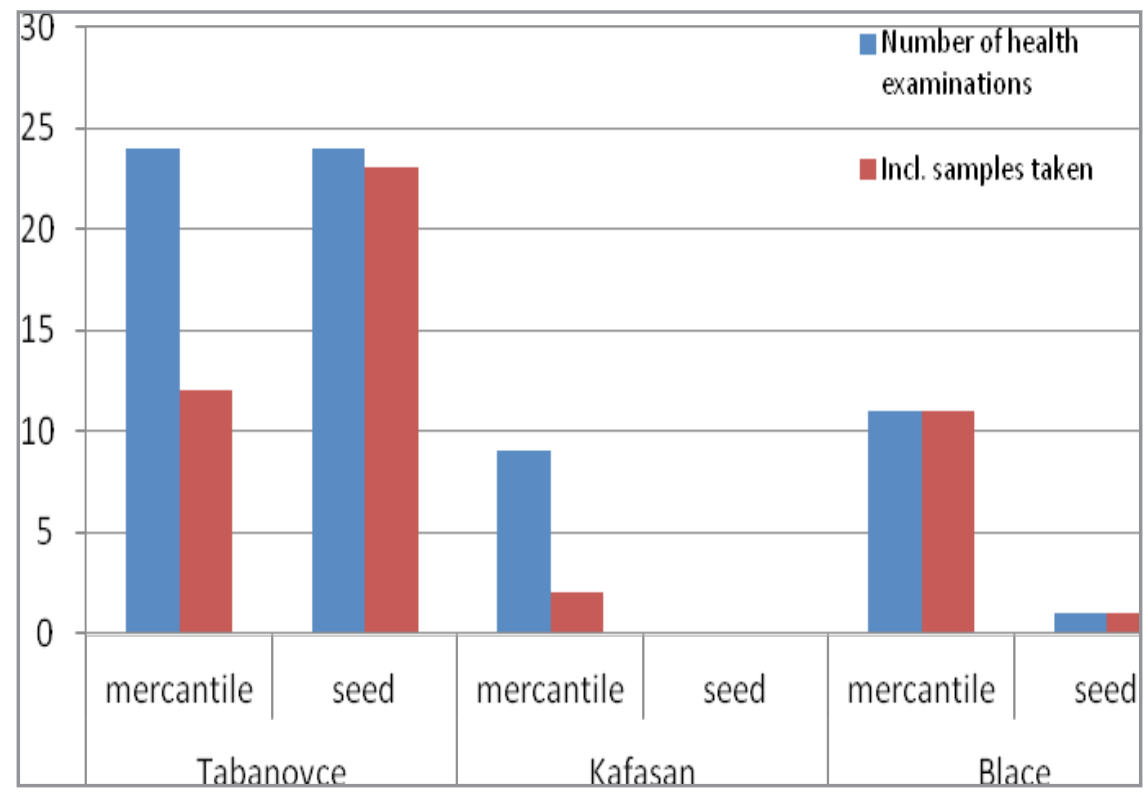

Figure 1. Number of visual health examinations performed, and laboratory samples taken analysis of three border crossings in 2014.

It should be noted that the control of imported material, whether it is seed or mercantile, does not end the work of state phytosanitary inspectors, their work continues on the field during the production process and storage. Phytosanitary control continues throughout the territory or country by region. In 2015, it can be seen that almost all seed material, in terms of the number of visual health examinations and analyzed samples, is at cross border Tabanovce (32), which can be seen from Table 2 and Figure 2).

The percentage of visual health examinations performed in relation to total samples taken for laboratory analysis differs in terms of mercantile and seed material. In 2015, at the Tabanovce border crossing, 32 visual health examinations of potato seed material were performed, while only 5 were taken for further laboratory analysis.

The difference between the total samples taken for laboratory analysis in terms of the number of visual health examinations performed was 34 , the laboratory analyzes were 7. The average rehearsals for all three border crossings for 2015 amounted to 5.7 number of visual health examinations performed and 1.2 total samples taken for laboratory analysis. The deviations between the two types of materials (mercantile and seed) in terms of visual health examinations and laboratory samples were greater than 2014 and were significantly different between groups and accounted for 12.9 and 1.9 , respectively.

It should be noted that all data subject to this research are in accordance with the monitoring programmes developed by the Republic of North Macedonia, which monitoring programs are developed each year. They are prepared at the end of the year for the following year. Monitoring programmes vary each year not only by cultures, but also by specific cultures as well as this research to see the number of visual health examinations and laboratory analyzes performed.

They are based on the assessment of the danger of introduction, and then the emergence and further spread of certain harmful organisms by the introduction of seed and seed material from the crops, considering the available data from the past period for the presence or absence of harmful organisms in our country. 
Table 2. Number of healthcare performed (visual and laboratory analysis) of mercantile and seed material imported in 2015 at three cross-borders.

\begin{tabular}{llcccc}
\hline Cross-boarder & Material & $\begin{array}{r}\text { Number } \\
\text { of visual } \\
\text { healthcare }\end{array}$ & $\begin{array}{r}\text { Total number } \\
\text { of samples for } \\
\text { analyses }\end{array}$ & $\begin{array}{r}\text { Difference / } \\
\text { Number / } \\
\text { samples }\end{array}$ & $\begin{array}{r}\text { \% analyses/ } \\
\text { Check } \\
\text { number }\end{array}$ \\
\hline \multirow{2}{*}{ Tabanovce } & Mercantile & 0 & 0 & 0 & $/$ \\
& Seeds & 32 & 5 & -27 & $-84 \%$ \\
\hline \multirow{2}{*}{ Kafasan } & Mercantile & 0 & 0 & 0 & $/$ \\
& Seeds & 1 & 1 & 0 & $0 \%$ \\
\hline \multirow{2}{*}{ Blace } & Mercantile & 0 & 0 & 0 & $/$ \\
\hline Total number & Seeds & 1 & 1 & 0 & $0 \%$ \\
Average & 34 & 7 & -27 & -0.84 \\
\hline Medium value error & 5.7 & 1.2 & -4.5 & -0.3 \\
Mediana & 5.3 & 0.8 & & \\
Modus & 0.5 & 0.5 & & \\
Standard deviation & 0.0 & 0.0 & & \\
Minimum & 12.9 & 1.9 & & \\
Maximum & 0.0 & 0.0 & & \\
\hline
\end{tabular}

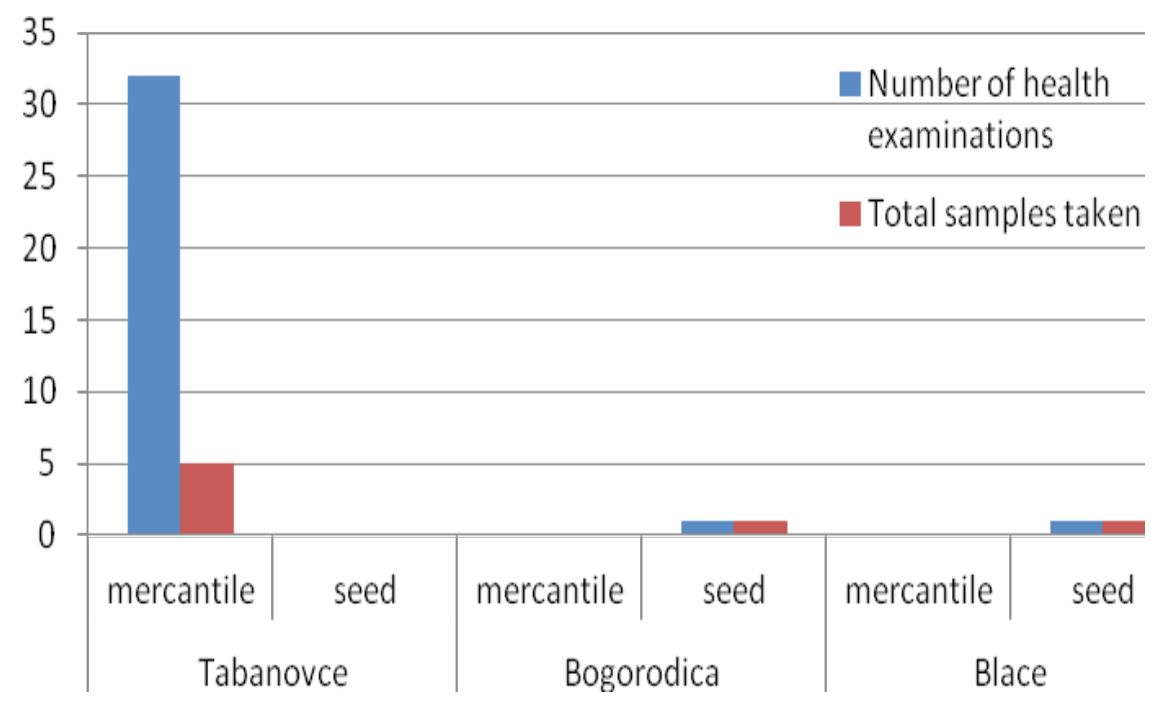

Figure 2. Number of visual health examinations performed and laboratory samples taken analysis of three border crossings in 2015.

In 2016, the state of visual health examinations of mercantile and seed material as well as the total samples taken for laboratory analysis did not differ with respect to the border crossings. Thus, the Tabanovce crossborder has the highest number of both visual and laboratory analyzed samples 19 and 17, in relation to Bogorodica and Novo Selo (Table
3). The difference between the visual health examinations and the laboratory analyzed samples of Tabanovce is minimal and it is $11 \%$. Of the three border crossings on average for 2016, samples of mercantile and seed material were visualized 7 , while laboratory analyzes were 6. 
Table 3. Number of healthcare performed (visual and laboratory analysis) of mercantile and seed material imported in 2016 at three cross-borders.

\begin{tabular}{|c|c|c|c|c|c|}
\hline Cross-boarder & Material & $\begin{array}{r}\text { Number } \\
\text { of visual } \\
\text { healthcare }\end{array}$ & $\begin{array}{r}\text { Total number } \\
\text { of samples for } \\
\text { analyses }\end{array}$ & $\begin{array}{r}\text { Difference / } \\
\text { Number / } \\
\text { samples }\end{array}$ & $\begin{array}{r}\text { \% analyses/ } \\
\text { Check } \\
\text { number }\end{array}$ \\
\hline \multirow{2}{*}{ Tabanovce } & Mercantile & 19 & 17 & -2 & $-11 \%$ \\
\hline & Seeds & 0 & 0 & 0 & I \\
\hline \multirow{2}{*}{ Kafasan } & Mercantile & 1 & 1 & 0 & $0 \%$ \\
\hline & Seeds & 0 & 0 & 0 & / \\
\hline \multirow{2}{*}{ Blace } & Mercantile & 1 & 1 & 0 & $0 \%$ \\
\hline & Seeds & 0 & 0 & 0 & / \\
\hline \multicolumn{2}{|l|}{ Total number } & & 19 & -2 & -0.11 \\
\hline \multicolumn{2}{|l|}{ Average } & & 3.2 & -0.3 & 0.0 \\
\hline \multicolumn{2}{|c|}{ Medium value error } & 3.1 & 2.8 & & \\
\hline \multicolumn{2}{|c|}{ Mediana } & 0.5 & 0.5 & & \\
\hline \multicolumn{2}{|c|}{ Standard deviation } & 7.6 & 6.8 & & \\
\hline \multicolumn{2}{|c|}{ Minimum } & 0.0 & 0.0 & & \\
\hline \multicolumn{2}{|l|}{ Maximum } & 19.0 & 17.0 & & \\
\hline
\end{tabular}

The median of both types of samples of visual health examinations is 0.5 , which is the same for the two groups, so that the difference of mean values obtained from all samples is close, and it is observed that most samples are analyzed from one place. Also, the deviation is not high and is small between groups or little variability in terms of visual (7.6) and analyzed samples (6.8) Table 3.

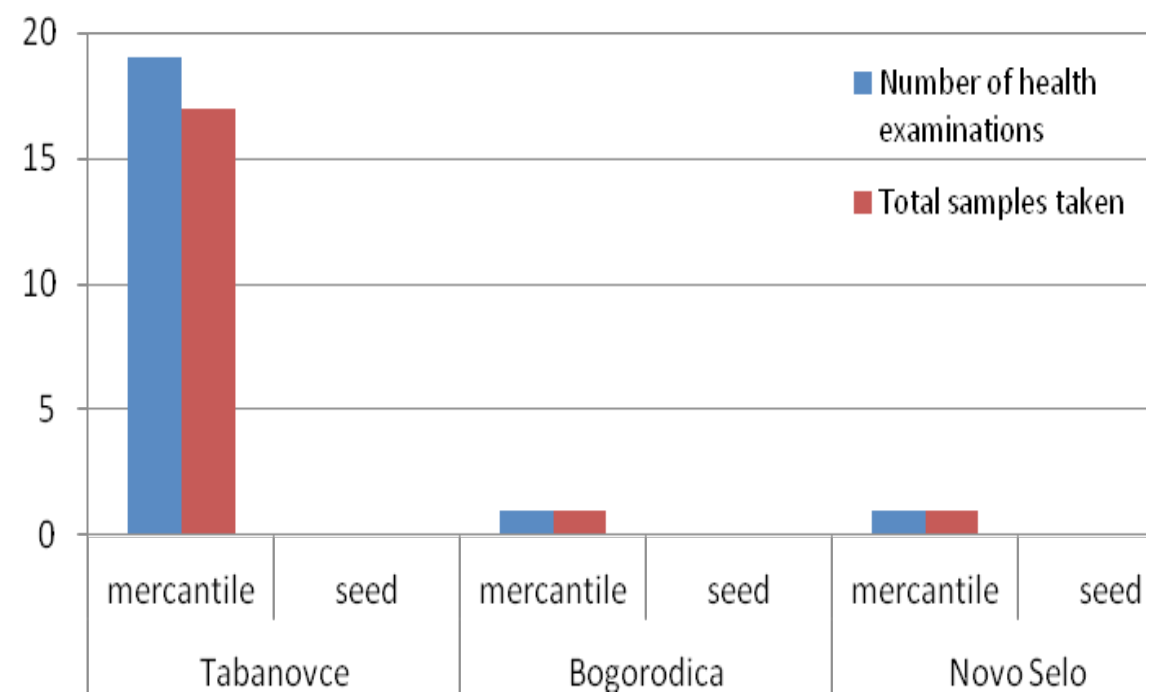

Figure 3. Number of visual health examinations performed and laboratory samples takenanalysis of three border crossings in 2016.

The medical examinations and samples taken for analysis at the Tabanovce cross border points as well as Bogorodica and Novo Selo are of mercantile material (Figure 3).

Compared to all years, visits and percentages of visual health examinations and laboratory analyzes, compared to total visits, for 2014, 2015 and 2016, potato varied by more than $20 \%$. Thus, the number of visual health examinations performed for the three years is 507 , and the total number of border checkpoints is 1,511 or $34 \%$ difference compared to the examinations related to seed and mercantile potatoes and total examinations.

The total samples taken for laboratory analysis of potato (seed and mercantile) in 
these three years is 251 , while the total analyzed laboratory samples are 1,161 or $22 \%$ difference. The difference between the visual health examinations and the analyzed laboratory samples for this period is 256 examinations, while the total border crossing examinations compared to the visual and analyzed laboratory samples is 350 analyzed samples or $27 \%$ more.

According to the 2017 Phytosanitary Policy Program for health examinations carried out in production regions and border crossings to determine the presence or absence of harmful organisms, due to the probability of possible risks of harmful organisms to seed and mercantile potatoes, garden crops, fruit species, vines and tobacco, a total of 764 samples and 1234 harmful organisms were examined.

Out of the total number of seed and mercantile potatoes 349 health examinations were performed, and 323 harmful organisms were examined. As of 2017, the Phytosanitary Directorate, on the recommendation of experts from the European Commission, does not develop monitoring programs on the basis of the number of performed health or laboratory analyzes, but on the basis of examinations or laboratory analyzes of harmful organisms.

Table 4. Number of healthcare performed (visual and laboratory analysis) of mercantile and seed material imported in 2017 at three cross-borders.

\begin{tabular}{|c|c|c|c|c|}
\hline $\begin{array}{c}\text { Region and cross- } \\
\text { borders }\end{array}$ & $\begin{array}{c}\text { Number of } \\
\text { predicted harmful } \\
\text { organisms }\end{array}$ & $\begin{array}{l}\text { Number of harmful } \\
\text { tested organisams }\end{array}$ & $\begin{array}{c}\text { Number } \\
\text { provided / } \\
\text { examined }\end{array}$ & $\begin{array}{c}\text { Percentage } \\
\text { analysis / } \\
\text { views } \\
\end{array}$ \\
\hline Polog & 18 & 18 & 0 & $0 \%$ \\
\hline Southwest & 14 & 13 & -1 & $-7 \%$ \\
\hline Northeast & 72 & 59 & -13 & $-18 \%$ \\
\hline Skopje region & 30 & 40 & 10 & $33 \%$ \\
\hline Southeast & 27 & 27 & 0 & $0 \%$ \\
\hline Pelagonia & 13 & 8 & -5 & $-38 \%$ \\
\hline Eastern & 68 & 53 & -15 & $-22 \%$ \\
\hline Vardar region & 9 & 7 & -2 & $-22 \%$ \\
\hline Cross-borders & 98 & 98 & 0 & $0 \%$ \\
\hline Total & 349.0 & 323.0 & & \\
\hline Average & 38.8 & 35.9 & & \\
\hline Total number of samples & 251 & 225 & & \\
\hline $\begin{array}{l}\text { Average of samples per } \\
\text { region }\end{array}$ & 31.4 & 28.1 & & \\
\hline Average value & 8.8 & 7.2 & & \\
\hline Mediana & 22.5 & 22.5 & & \\
\hline Standard deviation & 24.88 & 20.34 & & \\
\hline Minimum & 9.0 & 7.0 & & \\
\hline Maximum & 72.0 & 59.0 & & \\
\hline
\end{tabular}

The total number of predicted harmful organisms for 2017 is 349 or 251 from the regions and 98 from the border crossings. The average number of predicted harmful organisms injects 38.8. The number of examined (laboratory analyzed) harmful organisms per region is 225 and 98 from the border crossings. The difference between the regions in the visual samples and the laboratory analyzed amounts to a minimum of 26 trials, with no differences at the border crossings.

This leads to the conclusion that in 2017 these differences between the two predicted and investigated parameters are unified. This mediation also indicates the median elapsed, i.e. the mean values of the set of values equal to 22.5 for both parameters. 
Table 5. Number of visual health examinations and laboratory analyzes of mercantile and seed material imported from 2014 to 2016 carried out at all border crossings.

\begin{tabular}{llcc}
\hline Cross-border & Material & Number of healthcare control & Laboratory analyses \\
\hline \multirow{2}{*}{ Tabanovce } & Mercantile & 91 & 50 \\
& Seeds & 29 & 28 \\
\hline \multirow{2}{*}{ Blace } & Mercantile & 14 & 14 \\
& Seeds & 2 & 2 \\
\hline \multirow{2}{*}{ Bogorodica } & Mercantile & 1 & 1 \\
& Seeds & 0 & 1 \\
\hline \multirow{2}{*}{ Kafasan } & Mercantile & 9 & 2 \\
& Seeds & 0 & 0 \\
\multirow{2}{*}{ Novo Selo } & Mercantile & 1 & 1 \\
& Seeds & 0 & 0 \\
\hline \multirow{2}{*}{ Average mercantile } & & 23.2 & 13.6 \\
Average seeds & & 6,2 & 6.2 \\
\hline \multirow{2}{*}{ Average mercantile } & & 116 & 68 \\
Average seeds & & 31 & 31 \\
\hline
\end{tabular}

The number of visual health examinations of mercantile and seed material for the period 2014 to 2016 averaged 23.2 in all border crossing mercantile potatoes and 6.2 seed potato material in terms of the number of visual health examinations performed, and samples for laboratory analysis 13.6 mercantile and 6.2 potato seed material (Table 5).

The total number of mercantile potato material for visual health examinations in this period was 116, and laboratory analyzed samples 68. For seed material, the number of health examinations was 31 , as well as laboratory analyzed samples.

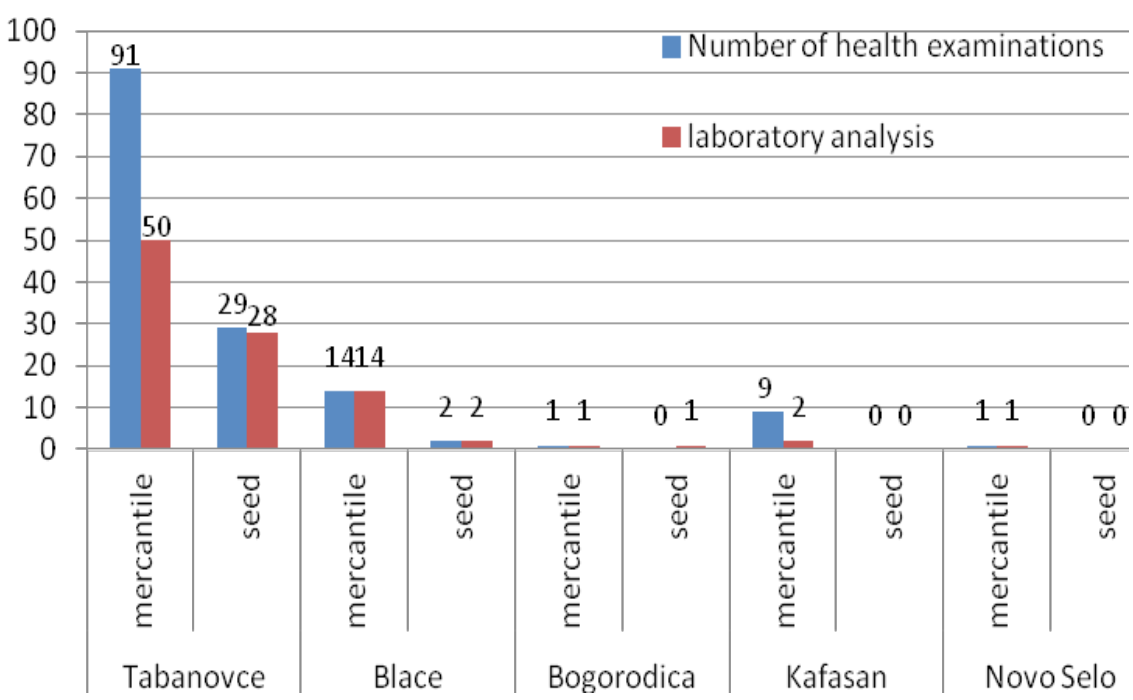

Figure 4. Number of visual health examinations performed and samples taken for laboratory analysis of all border crossings 2014-2016.

As individually by years and total for the three years 2014, 2015 and 2016, Tabanovce cross border point has the highest number of performed visual health examinations as well as laboratory analyzed samples 75 and 34 which can be clearly seen from Figure 4 .
Imports of mercantile and potato seed material vary throughout the period of this research. The largest import of mercantile potatoes made in 2014 (3,044t), which is the largest material ever imported in the years taken as the subject of this research. The least mercantile potato was imported in 2017 (110t). 
Table 6. Import of seed and mercantile potatoes in the Republic of North Macedonia in the period 2014 to 2017 in tons.

\begin{tabular}{|c|c|c|}
\hline Year & Material & Import od seed and mercantile potato in $\mathbf{t}$ \\
\hline \multirow{2}{*}{2014} & Mercantile & 3.044 \\
\hline & Seeds & 1.434 \\
\hline \multirow{2}{*}{2015} & Mercantile & 1.210 \\
\hline & Seeds & 1.061 \\
\hline \multirow{2}{*}{2016} & Mercantile & 1.110 \\
\hline & Seeds & 842 \\
\hline \multirow{2}{*}{2017} & Mercantile & 7.386 \\
\hline & Seeds & 1.010 \\
\hline \multirow{2}{*}{ Total (2014-2017) } & Mercantile & 12.750 \\
\hline & Seeds & 4.347 \\
\hline \multirow{2}{*}{ Average (2014-2017) } & Mercantile & 3.188 \\
\hline & Seeds & 1.087 \\
\hline
\end{tabular}

The largest import of seed material was imported in 2014 at $1.434 \mathrm{t}$, while the least imported in 2016 at $842 \mathrm{t}$ (Table 6 and Figure 5).
The average annual mercantile potato imports are around $3.188 \mathrm{t}$ and the import of seed potatoes is $1.087 \mathrm{t}$.

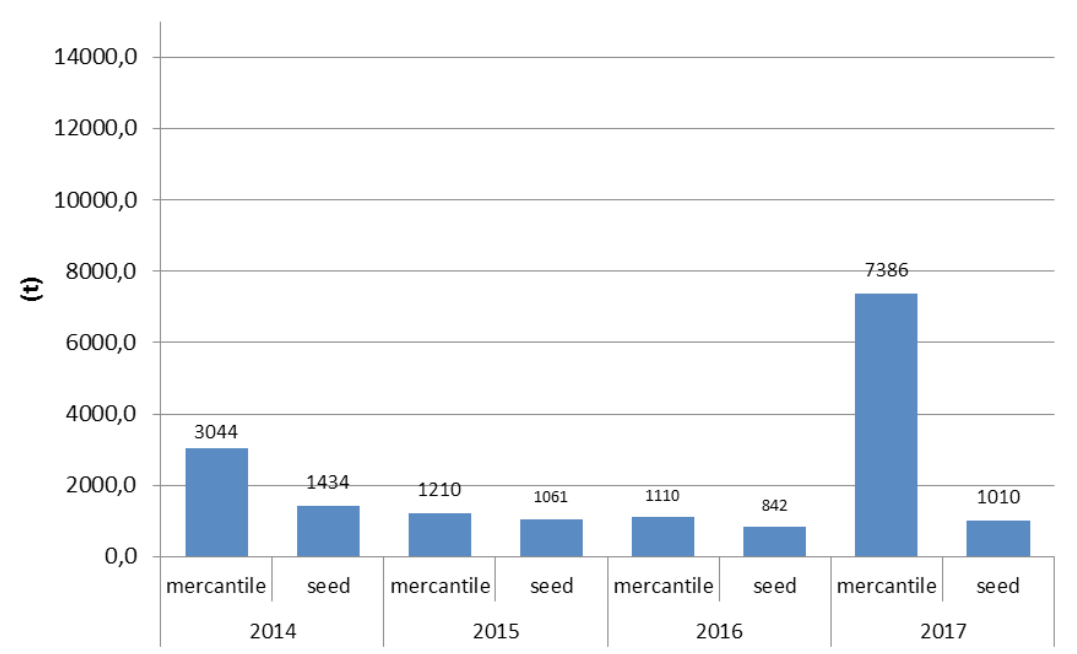

Figure 5. Import of mercantile and seed potatoes in the period from 2014 to 2017 in tons.

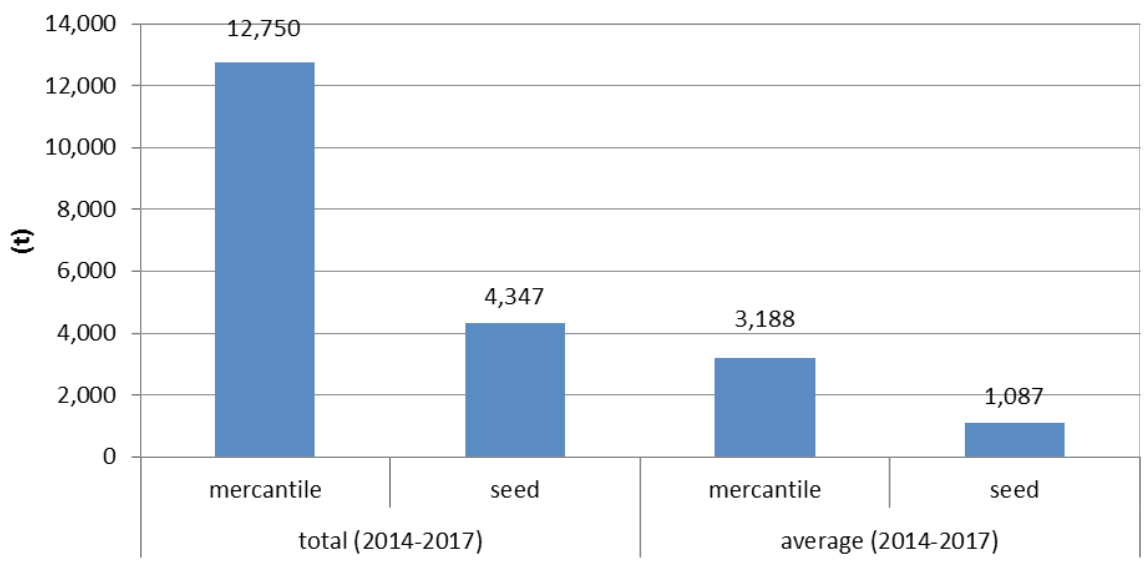

Figure 6. Total and average quantities of mercantile and seed potatoes in the period 2014 to 2017. 


\section{CONCLUSION}

Individually, both by years and total for all years of research 2014, 2015, 2016 and 2017 at the Tabanovce cross-border has the highest number of both performed visual health examinations and laboratory analyzed samples. The largest import of seed material was imported in 2014 of $1.434 \mathrm{t}$, while the least was imported in 2016 of $842 \mathrm{t}$. For the period 2014 to 2017, annual imports averaged about 4.347 $\mathrm{t}$ of seed potatoes and $12.750 \mathrm{t}$ of mercantile potatoes. The average annual mercantile potato imports are around $3.188 \mathrm{t}$, and the import of seed potatoes is $1.087 \mathrm{t}$.

This study confirmed that the presence of the following harmful organisms (Ralstonia solacearum, Clavibacvter michiganensis ssp. sepedonicus; Synchitrium endobioticum; Globodera pallida and Globodera rostochiensis, has not been established (no introduction, occurrence and further spread).

\section{REFERENCES}

EPPO PM 7/28 (1), 2003 Evidence and identification of Synchytrium endobioticum by macroscopic visualization and microscopy in potato tubers.

EPPO standard CD 2006/56 / EC, 2006 Immunofluorescence test (IC test) to prove and identify the bacterium Clavibacter michiganensis ssp. sepedonicus in Potato Tubers

EPPO standard CD 2006/63 / EC, 2006 Immunofluorescence test (IC test) for the detection and identification of Ralstonia solanacearum in potato tubers.

FAO STAT Agriculture (2012). FAO statistical database. http://www.fao.org/corp/statistics/en/

Islam, M.S. and Chowdhury A.R. (1998). Virus free stock production of some indigenous potato varieties of Bangladesh. Plant Tissue Culture. 8 (1): 41-47.

Law on Plant Health ("Official Gazette of the Republic of North Macedonia No. 29/05, 81/08, 20/09, 57/10, 17/11, 148/11, 69/13, 43/14 and $158 / 14)$

"Official Gazette of the Republic of North Macedonia" no. 62/17": Order to conduct special surveillance to establish presence cystolic nematodes Globodera pallida (Stone) Behrens and Globodera rostochiensis (Wollenweber) Behrens on potatoes and plants their hosts, determining their distribution, the measures which should be taken in the event of their occurrence, as well as the procedures for laboratory analysis

"Official Gazette of the Republic of North Macedonia" no.151/14: Law on Seed and Planting Material for Agricultural Plants

"Official Gazette of the Republic of Northern Macedonia" No. 65/10 Lists of harmful organisms, plants, plant products and more objects and objects

"Official Gazette of the Republic of Northern Macedonia" No. 88/00 Order on Measures for Import of Potatoes into the Republic of Macedonia.

"Official Journal of the European Communities Republic of Northern Macedonia" no. 62/17: Order to carry out special supervision for the determination of the presence of the bacterium Ralstonia solanacearum (Smith) Yabuuchi et al. and laboratory test procedures

"Official Journal of the Republic of Northern Macedonia" no. 34/14: Order to conduct special surveillance to establish presence of the fungus Synchytrium endobioticum (Schilb.) Perc. and procedures for laboratory examination.

OostenbrinkM (1960) Estimating nematode populations by some selected methods. In Nematology (ed. Sasser JN \& Jenkins WR), pp. 85-102. The University of North Carolina Press, Chapel Hill, NC (US).

PM 7/119 (1) Nematode extraction, Bulletin OEPP/EPPO Bulletin (2013) 43 (3), 471-495, ISSN 0250-8052. DOI: 10.1111/epp.12077

Rulebook on Seed Potato Trade (Official Gazette of the Republic of Northern Macedonia No. 62/09)

Rulebook on the Manner of Conducting a Health Check and the Manner of sampling the garden crops outdoors and in the indoors over which phytosanitary monitoring is carried out ("Official Journal of the Republic of Northern Macedonia" no. 113/13)

Rulebook on the manner of conducting a health check and the manner of sampling of seed and mercantile potatoes over which they are performs phytosanitary monitoring ("Official Gazette of the Republic North Macedonia" no. 113/13)

Rulebook on the Manner of Performing Phytosanitary Inspection at import of consignments from list $V$, section $B$, section $1\left(^{*}\right)$ ('Official Journal of the European Union Republic of Northern Macedonia" no. 131/10) 


\title{
ЗДРАВСТВЕНАТА СОСТОЈБА НА КОМПИРОТ ПРИ УВОЗ ВО РЕПУБЛИКА СЕВЕРНА МАКЕДОНИЈА
}

\author{
Маја Петрушева ${ }^{*}$, Саша Митрев ${ }^{2}$, Емилија Арсов ${ }^{2}$ \\ "Универзитет "Гоче Делчев" - Штип, Земјоделски факултет, \\ Катедра за заштита на растенијата и животната средина, \\ студент на втор циклус студии \\ 2универзитет „Гоче Делчев" - Штип, Земјоделски факултет, \\ Катедра за заштита на растенијата и животната средина \\ *Контактавтор: mristevska62@yahoo.com
}

\begin{abstract}
Резиме
Идејата, целта и резултатите од ова истражување се однесуваат на здравствената контрола при увоз, како и земањето на мостри на граничните премини (места) на влез во Република Северна Македонија, за временскиот период 2014-2017 год., кај примероци од семенски и меркантилен компир. Испитувањата беа направени согласно со мониторинг програмата за семенски и меркантилен компир, а се однесуваат за докажување на присуство односно отсуство на следниве штетни организми: бактериско венење и кафеаво гниење на компирот - Ralstonia solanacearum, рак на компирот - Synchitrium endobioticum perc., прстенесто гниење на компирот - Clavibacter michiganensis subsp. sepedonicum, цистолики нематоди кај компирот Globodera pallida (Stone) Behrens и Globodera rostochiensis (Wollenweber) Behrens.

Поединечно, како по години така и вкупно за сите години од истражувањето (за периодот од 2014 год. заклучно со 2017 год.), на граничниот премин Табановце имаше најголем број на извршени здравствени визуелни прегледи, како и лабораториски анализи.

Најголем увоз на меркантилен компир е извршен во 2017 година - 7.386 t, а најмалку во 2016 година - 1.110 t. Најголем увоз на семенски материјал има во 2014 година - 1.434 t, додека најмалку е увезен во 2016 година - 842 t. Во период од 2014 до 2017 година е увезено повеќе меркантилен компир (12.750 t). За период од 2014 до 2017 година годишниот увоз во просек се движи околу $1.087 \mathrm{t}$ на семенски компир и $3.188 \mathrm{t}$ меркантилен компир. Програмата за мониторинг има значајна улога во детекција на штетници и болести пред истите да бидат внесени во земјата, што е случај и тука кај увозот на меркантилен и семенски компир. Доколку се појави одреден штетен организам, токму со раната детекција преку мониторингот ќе се овозможува поефикасно искоренување и нивно понатамошно ширење. Со ова истражување потврдивме дека штетните организми (Ralstonia solacearum, Clavibacvter michiganensis ssp. sepedonicus; Synchitrium endobioticum; Globodera pallida и Globodera rostochiensis) досега не беа потврдени (на гранични премини при увоз или понатамошно ширење).
\end{abstract}

Клучни зборови: компир, штетни организми, увоз, гранични премини 